\title{
Aminostratigraphy and sea-level history of the Pleistocene Bridgewater Formation, Mount Gambier region, southern Australia
}

A. G. BLAKEMORE ${ }^{1}$, C. V. MURRAY-WALLACE ${ }^{1 *}$, K. E. WESTAWAY ${ }^{2}$ AND T. J. LACHLAN $^{1}$

${ }^{1}$ School of Earth \& Environmental Sciences, University of Wollongong, NSW 2522, Australia

${ }^{2}$ Department of Environment and Geography, Macquarie University, Sydney, NSW 2109, Australia

*e-mail: cwallace@uow.edu.au

\section{SUPPLEMENTARY PAPERS}

Australian Journal of Earth Sciences (2015) 62, 151-169.

http://dx.doi.org/10.1080/08120099.2015.1014523

Copies of Supplementary Papers may be obtained from the Geological Society of Australia's website (www.gsa.org.au), the Australian Journal of Earth Scienecs website (www.ajes.com.au) or from the National Library of Australia's Pandora archive (http://nla.gov.au/nla.arc-25194).

\section{SUPPLEMENTARY PAPER}

Appendix: Details of sample sites. 


\section{APPENDIX - DETAILS OF SAMPLE SITES}

\section{A1 - Port MacDonnell Beach and Robe Range}

Port MacDonnell Beach, approximately $25 \mathrm{~km}$ seaward of Mount Gambier exposes a range of coastal successions including stacked eolianite units, a raised Holocene Beach, outcrops of Oligo-Miocene Gambier Limestone and a paleobeach facies of MIS 5c age, all of which are described in Blakemore et al. (2014). The paleobeach facies is used as the primary sea-level indicator at this site and is currently located within the present tidal zone. At its time of formation it would have been within $\pm 2 \mathrm{~m}$ of mean sea-level.

\section{A2 - Last interglacial deposits}

\section{MACDONNELL RANGE}

MacDonnell Range trends subparallel to the modern coastline and is located $7 \mathrm{~km}$ inland from Port MacDonnell. Blakemore et al. (2014) identified the barrier sequence to be last interglacial (MIS 5e) in age and an extension of the Woakwine Range. The sample site is a small sand quarry (S37 $\left.13^{\prime} 53.4^{\prime \prime}, \mathrm{E} 140^{\circ} 01^{\prime} 14.5^{\prime \prime}\right)$ approximately $5 \mathrm{~km}$ east of Allendale East which revealed mostly free-flowing, pale yellow (2.5Y 8/2), medium grained mixed quartz-skeletal carbonate sand. At two locations within the quarry, semi-consolidated and laminar cross bedding is evident where beds dip $14^{\circ} \mathrm{S}$. A $30 \mathrm{~cm}$ thick dark brown soil profile caps the succession and within which weakly developed rubbly calcrete is also present. Beneath the soil profile a $1 \mathrm{~m}$ thick layer of rhizoliths indicates past dune vegetation.

\section{LAKE HAWDON SOUTH}

A lagoonal facies of last interglacial age was identified in the lee of Woakwine Range, within Biscuit Drain (S 37¹3'53.4”, E 14001'14.5”), near Lake Hawdon South. The exposure is $1.25 \mathrm{~m}$ deep and blanketed by a $30 \mathrm{~cm}$ thick massive calcrete. A $25 \mathrm{~cm}$ thick shell bed occurs at the base of the cutting and comprises densely packed, commonly articulated species including: Brachidontes rostratus, Chlamys bifrons, Katelysia rhytiphora, Fulvia tenuicostata, Spisula (Notospisula) trigonella, Tellina deltoidalis and Anadara trapezia - a bivalve no longer living in South Australian waters and an indicator of deposition during warmer sea surface temperatures during MIS 5e (Cann \& Clarke 1993; Murray-Wallace et al. 2000). The shell bed rests upon a layer of mature, articulated Ostrea angasi, which are commonly found in deeper water and attest to a previous connection with the open sea. Above the shelly units 
sediment becomes finer towards the top of the cutting signifying a shoaling upwards succession.

\section{A3 - Burleigh Range}

\section{RABBITORS ROAD}

Burleigh Range, $13 \mathrm{~km}$ inland from Port MacDonnell, also trends subparallel to the modern coastline and is a southern extension of Reedy Creek Range. A road cutting along Rabbitors Road (S 37²3'17.7', E14046'06.9”) exposes three lens-shaped, seaward dipping gravel beds, separated by finely bedded, pale yellow (2.5Y 8/4) medium-grained sand, 36 m APSL. This site was previously described by MurrayWallace et al. (1996). The flint cobbles lenses within Burleigh Range are similar to the flint cobble beach ridges found at the modern coastline, within the tidal zone, at Racecourse Bay, $5 \mathrm{~km}$ east of Port MacDonnell. It is therefore suggested that the flint cobbles within Burleigh Range would have formed within $\pm 2 \mathrm{~m}$ of mean sea-level.

\section{LASLETT ROAD}

Laslett Road extends eastward and perpendicular to Rabbitors Road and exposes a lagoonal facies in the immediate lee of Burleigh Range (S3756'30.9”, E140 47'42.7'). The cutting is approximately $4 \mathrm{~m}$ deep and a weathering crust has developed of the face of the exposure. Where exposed, calcarenite displays very fine, predominantly laminar bedding within pale yellow (2.5Y 8/2), fine-grained sand. Well-preserved shells of Mactra and Brachidontes are common within the succession but are not articulated and have been transported post mortem. Bioturbation in the form of vertical burrows is also evident. Lagoonal facies may have been deposited beneath a water depth of approximately $1 \mathrm{~m}$. This water depth would have been approximately at mean sea-level and thus lagoonal facies can provide an indication of paleosea-level with an uncertainty of $\pm 1 \mathrm{~m}$.

\section{A4 - Caveton Range}

A lagoonal facies, $38 \mathrm{~m}$ APSL, is exposed within a silage pit cutting leeward of Caveton Range (S37 $54^{\prime} 06.2^{\prime \prime}$, E14046'18.5”). Eleven layers of laminated, light grey to pale yellow fine to very fine sand are exposed. Marine mollusc species present include Tellina deltoidalis, Katelysia rhytiphora, Niotha pyrrhus, Fulvia tenuicostata, Anapella cycladea and Modiolus areolatus. Abundant foraminifers within the sediment include Ammonia beccarri, Discorbis dimidiatus and small tests of Elphidium crispum. These fauna are indicative of muddy and estuarine environments. This site was previously described by Murray-Wallace et al. (1996). As previously 
mentioned lagoonal facies in this region provide an indication of paleosea-level with an uncertainty of $\pm 1 \mathrm{~m}$.

\section{A5 - Gambier Range}

A small cutting within the Bridgewater Formation was identified within Myora Forest, Gooch Road (S3754'11.3”, E14051'25.9”), 50 m APSL. The cutting is $4 \mathrm{~m}$ deep, 15 $\mathrm{m}$ wide and exposes gently $\left(4-6^{\circ}\right)$, northeasterly dipping laminar beds. The bedding is well cemented, within free-flowing, brownish yellow (10YR 6/8) fine to medium sand, found between cemented layers. No marine molluscs were identified but the foraminifers Elphidium crispum and Discorbis dimidiatus are abundant. No distinct calcrete horizon or other subaerial exposure features such as solution pipes or rhizoliths are present. It is not possible to determine paleowater depth at this locality due to the lack of diagnostic sea-level indicators other than finely laminated beds. All that can be discerned is that sea-level at the time of deposition was at least this elevation and likely several metres higher as no bedforms associated with swash processes are evident.

\section{A6 - Compton Range}

\section{BAXTER'S QUARRY}

Within Baxter's Quarry, Mount Gambier, (S3749'05.6”, E14047'20.4”) a north-facing wall, $5 \mathrm{~m}$ high and $75 \mathrm{~m}$ long, reveals distinct cross bedding within calcarenite of the Compton Range. Large (up to $75 \mathrm{~cm}$ wide and $350 \mathrm{~cm}$ deep) solution pipes are common and the presence of rhizoliths and a thick red terra rossa soil are indicative of subaerial exposure. A laterally persistent unconformity, $1 \mathrm{~m}$ below the top of the wall, occurs across the entire length of the exposure. A $15 \mathrm{~cm}$ thick paleosol occurs beneath the unconformity. The unconformity separates two distinct bedding patterns. Overlying the unconformity beds are thicker and of a higher angle signifying eolian deposition and the succession is termed here Compton I following the stratigraphical scheme introduced by Sprigg (1952) and Schwebel (1978, 1984). This unit is at $50 \mathrm{~m}$ APSL. Below the unconformity beds are much finer, more laminar and in places herringbone bedding is present signifying subaqueous deposition (Compton II) at 47 m APSL. An OSL sample was collected from the upper eolian unit (Compton I) at the eastern end of the quarry wall (Figure 2). AAR sediment samples were collected from both the upper and lower units. The herringbone bedding within Compton II is indicative of a swash zone setting and may have formed in a water depth between 2 and $10 \mathrm{~m}$. Compton I is eolian and therefore must have formed above sea-level in the 
supratidal zone. Eolian facies would therefore have been deposited at least $2 \mathrm{~m}$ above sea-level.

\section{HERITAGE INDUSTRIES}

At Heritage Industries, an old saw mill, a south-facing wall, $16 \mathrm{~m}$ long and $5 \mathrm{~m}$ high, (S3749'37.2”, E14047'55.2”) reveals laminar and cross-bedded calcarenite within Compton Range. Multiple solution pipes, up to $1 \mathrm{~m}$ wide, are present and some are filled with a thick, red terra rossa soil. Sediment is composed of pale yellow (2.5Y 8/3) medium-grained sand. Three bands of fossil shells are identified within the lowest metre of the cutting and are dominated by disarticulated, but well-preserved valves of Ostrea angasi. Approximately $1.5 \mathrm{~m}$ higher within the exposure a more laterally extensive unit is identified, consisting of shell fragments and subrounded pebbles.

\section{A7 - Mingbool Range}

A small ( $30 \mathrm{~m}$ wide, $30 \mathrm{~m}$ deep) quarry (S3754'41.9”, E141 $\left.{ }^{\circ} 11^{\prime} 10.4^{\prime \prime}\right)$ within farmland in Mumbannar ('Don's Quarry'), western Victoria, reveals fine, consistently laminar beds, $\sim 3 \mathrm{~mm}$ thick, within yellow (10YR 7/6), fine-grained sand. A fine soil has developed but there is no evidence of other subaerial exposure features such as rhizoliths or solution pipes. Disarticulated shells of Ostrea angasi are found at the top of the cutting and within boulders of well-cemented calcarenite on the quarry floor.

\section{A8 - Dismal Range \\ DARTMOOR CEMETERY}

A large excavation $100 \mathrm{~m}$ in length and $6 \mathrm{~m}$ deep approximately $20 \mathrm{~m}$ west of Dartmoor Cemetery, western Victoria (S3754'55.6”, E141¹4'54.0”) reveals laminar bedding within the Dismal Range, $50 \mathrm{~m}$ APSL. Bedding within the exposure is uniformly laminar and fine, with beds $\sim 3-4 \mathrm{~mm}$ thick. At the western end of the exposure, low-angle trough-cross bedding is evident within the fine, pale yellow (2.5Y $8 / 4)$ sand. A small unit ( $30 \mathrm{~cm}$ by $15 \mathrm{~cm})$ of shell grit was identified below a set of low-angle trough-cross beds and signifies a higher energy environment such as a swash zone. Whole shells are commonly identified within the lower $2 \mathrm{~m}$ of the cutting, but are disarticulated and do not appear within a distinct shell layer. Two species were identified; Ostrea angasi and Pecten benedictus. These species are known to live in water depths of 2-20 m (Ludbrook 1984). Bioturbation structures are also common. Small solution pipes (up to $1 \mathrm{~m}$ in length) are confined to the upper portion of the exposure. 


\section{FORT O'HARE QUARRY}

A north-facing railway cutting at Fort O'Hare (S3755'44.7”, E141'17'15.3”) 1 km southeast of Dartmoor reveals fine, laminar bedding within pale yellow (2.5Y 7/4) calcarenite, $40 \mathrm{~m}$ APSL. The cutting is $\sim 8 \mathrm{~m}$ high and $150 \mathrm{~m}$ long. A densely packed, $75 \mathrm{~cm}$ thick shell bed occurs within the exposure. At the western end of the quarry, the shell bed is approximately $1 \mathrm{~m}$ from the floor of the cutting, but as the floor lowers eastward the relative height of the shell bed above the ground surface increases. At the western end of the cutting the shell bed is dominated by mature, articulated, wellpreserved shells of Ostrea angasi. Towards the centre of the exposure the shell bed remains dominated by Ostrea but also includes the species Pecten benedictus albus, Chlamys asperrima asperrima, and Chlamys (Equichlamys) bifrons. Above the shell bed a darker unit, $\sim 15 \mathrm{~cm}$ thick and slightly undercut relative to the surrounding calcarenite, is observed across the length of the exposure.

MINGBOOL VILLAGE

Approximately $18 \mathrm{~km}$ northeast of Mount Gambier and $5 \mathrm{~km}$ east of Mingbool a small quarry (S3741'38.6”, E14054'30.5”) reveals low-angle bedding within Dismal Range, 70 m APSL. Fine, low-angle, laminar and trough cross-bedding are visible within the very pale brown (10YR 8/3) fine-grained sand at several locations. Numerous shell fragments are visible within the calcarenite but are not within distinct shell beds. Numerous disarticulated shells are entire and include Ostrea angasi and Pecten, similar to the species identified at Fort O'Hare Quarry and Dartmoor Cemetery, some $50 \mathrm{~km}$ to the east within the same barrier. The fine bedding indicates the sediments were deposited within a subaqueous environment. The mollusc species present may have lived at a water depth of up to $30 \mathrm{~m}$ but as they are not identified here within an in situ death assemblage it is not possible to determine the paleowater depth.

\section{REFERENCES}

Blakemore A. G., Murray-Wallace C. V. \& Lachlan T. J. 2014. First recorded evidence of subaqueously-deposited late Pleistocene interstadial (MIS 5c) coastal strata above present sea level in Australia. Marine Geology 355, 377383

CANN J. H. \& CLARKE J. D. 1993. The significance of Marginopora vertebralis (foraminifera) in surficial sediments at Esperance, Western Australia, and in last 
interglacial sediments in northern Spencer Gulf, South Australia. Marine Geology 111, 171-187.

LudBRoOK N. H. 1984. Quaternary molluscs of South Australia. South Australia Department of Mines and Energy, Handbook 9. Adelaide SA.

Murray-Wallace C. V. Beu A. G., Kendrick G. W., Brown L. J., Belperio A. P. \& SHERWOOD J. E. 2000. Palaeoclimatic implications of the occurrence of the arcoid bivalve Anadara trapezia (Deshayes) in the Quaternary of Australasia. Quaternary Science Reviews 19, 559-590.

Murray-Wallace C. V., Belperio A. P., Cann J. H., Huntley D. J. \& Prescott J. R. 1996. Late Quaternary uplift history, Mount Gambier region, South Australia. Zeitschrift für Geomorphologie 106, 41-56.

SCHWEBEL D. A. 1978. Quaternary stratigraphy of the southeast of South Australia, Unpublished Ph.D thesis, Flinders University of South Australia.

SchWEBEL D. A. 1984. Quaternary stratigraphy and sea-level variation in the southeast of South Australia. In: Thom B. G. ed. Coastal Geomorphology in Australia, pp. 291-311. Academic Press, Sydney, NSW.

Sprigg R. C. 1952. The geology of the South-East Province, South Australia, with special reference to Quaternary coast-line migrations and modern beach developments. South Australia, Geological Survey Bulletin 29. Adelaide SA 